\title{
Megachurches as Total Environments
}

\author{
James K. Wellman Jr., Katie E. Corcoran and Kate J. Stockly
}

We argue that megachurches create and optimise total environments, which answer the desires of the human heart and generate an emotional energy that is both powerful and satisfying. By total environment, we mean a context that provides megachurch attendees with sufficient ministries, resources, and social ties such that attendees generally do not need to seek secular sources to have their fundamental emotional needs met. The megachurch and its activities provide a structure for their life. Megachurches build stable, confident, and encompassing sacred canopies for their members - virtually all of the material and emotional needs that accompany each stage of life and development are addressed. From early childhood development classes, through youth mission trips, on to marriage counselling, and, at least at one church in our study, a senior living facility on the church campus. The megachurch model must be understood as a comprehensive system - each element carefully crafted as a building block of what becomes a total environment protected by a comforting and nourishing sacred cocoon. The megachurch model is far from indestructible, and yet, as we have seen time and time again, even devastating scandals and dramatic cultural pressures barely touch the total system. Pastors may be ousted, but the megachurch model survives. The obvious question facing scholars and social critics alike is: How? What is so compelling about these churches? Why are they able to operate successfully as total environments?

All contexts and cultures have feelings rules-rules that tell people how they should feel and express their feelings in any particular moment for a given situation (Hochschild 2012). The current emotional climate of modern society is one in which people are highly aware of emotions with strict regulations on when, where, how, and by whom certain emotions should be expressed (Riis

1 Part of this chapter is reprinted and adapted with permission from James K. Wellman, Jr., Katie E. Corcoran, and Kate Stockly-Meyerdirk, “'God is Like a Drug...': Explaining Interaction Rituals in American Megachurches," Sociological Forum 29 (2014): 650-672. Copyright [2014] by Wiley and from James K. Wellman, Jr., Katie E. Corcoran, and Kate J. Stockly, High on God: How Megachurches Won the Heart of America, Oxford University Press (2020). Copyright [2020] Oxford University Press. 
and Woodhead 2010). Strong emotions are rarely encouraged in public places with the exception of sporting events (Riis and Woodhead 2010). We argue that megachurches are successful become they satisfy a demand for intense shared emotional expression in public places (see also Corcoran and Wellman 2016).

Echoing Randall Collins (2004) we begin with the knowledge that humans seek emotional energy through social engagement, in fact, emotional energy is the force that forms the foundation of human sociality. Humans desire emotional energy because it feeds their fundamental needs - not only for individual satisfaction, but also for the emotional fulfillment of joining with others while remaining oneself. In this way, emotional energy is central to how humans address what Emile Durkheim calls the problem or paradox of homo duplex: humans desire to be independent, masters of their own universe, sui generis individuals, but they must necessarily do this in and through others (Durkheim 1964). The viscerally felt embodied desire for emotional energy achieves the feat of complex human cooperation, because through cooperation, energy is generated that is, quite literally, a drug experience that sustains humans across time and every tradition.

The ligaments that construct this social matrix are rituals. Social interaction rituals function to initiate the generation of emotional energy and social bonds, and are then repeated to reinforce and recreate this solidarity. When moments of intense emotional energy occur, they are typically one of the highlights of a person's life, a peak experience that sometimes feels like a 'drug' high if you will, that binds people together and helps sustain them in times of isolation and differentiation. This desire to be one with others and one with self, when met, is an explosive combination of joy, deep contentment, and ecstasy. Christian megachurches ${ }^{2}$ and their characteristic ritual structure are enormously successful in making this experience available and possible for human beings.

When our megachurch informants said, "I feel like I'm high on God", it made us wonder at first, "Is this a drug trip? Is it some form of phony manipulation?" Of course, we are very aware of the dark side of megachurches. There is little doubt that in any complex, humanly constructed social form, especially those with hierarchical power structures, scandal is rife and manipulation is not uncommon. But, in general, that is not our thesis. To put it boldly, the megachurch experience is a drug that works. And we don't mean this as a problem but as a solution to the dilemma of homo duplex.

2 Megachurches are defined as Protestant congregations with weekly worship attendance of 2,000 or more adults and children. 
In this chapter, we present a summary of our theory of the Megachurch Ritual Cycle-a model for church that has taken over the market for megachurches and proven to be very successful. The Megachurch Ritual Cycle is comprised of six components or links that provide a powerful cumulative experience; we'll outline these six steps below: welcoming ethos, awe-inspiring worship, sermon providing reliable leadership, altar call inviting transformation, service projects, and small-groups. Along the way, we present our own theory for how people are drawn to participate and invest in these rituals; we call this embodied choice theory, and it is in large part based on the insights of Randall Collins's theory of interaction ritual chains (Collins 2004). We support our theory with qualitative data from interviews with megachurch attendees and pastors. We argue that the Megachurch Ritual Cycle enhances, manages, and directs what Collins calls emotional energy with which megachurches are overflowing, in a way that facilitates a total environment. We show how Durkheim's theory of homo duplex is addressed through megachurch rituals.

Our argument is simple and to the point: megachurches have understood the ways to create, motivate, and charge their congregations with emotional energy that stimulates intense loyalty and visceral desire to return repeatedly for a recharge. In this way, megachurches are like drug dealers offering members and non-members alike their next hit. They have perfected ways to produce and mark human experience so that it is reproduced and creates a positive and life-sustaining energy. Interpreted as the physical manifestation of God's love and Christ's supernatural presence, this emotional energy becomes the life-blood of attendees that draws them back and binds them together in a total environment. In what follows, we show that the creation of dramatic, emotionally powerful rituals is no small feat. Whether those who facilitate megachurches know it or not, they have created a ritual system that speaks to the human desire for emotional energy and is one of the most successful religious structures in America today.

Since 1992, Thumma and Bird (2011) have tracked the known population of all American megachurches - Protestant (Thumma and Travis 2007) ${ }^{3}$

3 Thumma and Travis (2007, xviii) note that while "there are many American Catholic and Orthodox churches, and a few synagogues and mosques, that serve over two thousand attendees in an average week," those "churches are organized and led in distinctively different ways that separate them as unique phenomena from Protestant megachurches". 
congregations with weekly worship attendance of 2,000 or more adults and children - and have compiled them into a Database of Megachurches in the U.S., providing a rough census of American megachurches. There were a total of 1,250 such congregations in 2007. From this 2007 census, Thumma and Bird selected twelve megachurches that represent the national megachurch profile in terms of a wide variety of characteristics including attendance, region, denomination, dominant race, and church age.

While these churches were selected to be representative of the entire population, the sample slightly under-represents the western region and is slightly larger than the average megachurch (Thumma and Bird 2009). In 2008, at each church, Thumma and Bird conducted focus groups and the interviews were transcribed. Leadership Network, a non-profit consultancy and research group, funded and collected this data and we are using it with permission. We personally observed at least one worship service at each church and read through and coded various church materials provided on their websites. We also incorporate observations of megachurch worship services from other megachurches. While we use the interviews as our primary source of data, we combine these data sources to provide a more comprehensive picture of megachurches.

During the focus groups, respondents answered questions about how they came to the church; how they became involved in their church, and in what ways they had, or had not, experienced spiritual growth at the church. Because responses may vary by type of attendee, in each church, three separate focus groups were conducted with newcomers (i.e., have been attending the megachurch for 3 years or less), longtimers (i.e., have been attending the megachurch for 4 years or more), and lay leaders (i.e., perform some form of leadership role in the church). The focus group interviews lasted approximately one hour and a half. Our three-person research team read, discussed, and coded transcriptions of the interviews. We coded 282 interviews ( 150 females, 132 males): 81 newcomers (NCs), 91 longtimers (LTs), and 110 layleaders (LLs).

\section{$3 \quad$ Homo Duplex and Ritual}

Durkheim's description of human nature as homo duplex is at the heart of our understanding of why and how megachurches function so well to orient and to provide community (Durkheim 1964). In a fundamental way, Durkheim's description of the profane and the sacred is captured in the movement from our existential and individual isolation to an interactive and cooperative group. This movement from the individual to the social group is neither smooth nor automatic, but to survive we must cooperate, and achieving this cooperation is 
experienced as both a challenge and a gift. A gift, not only because it means our survival, but also, being facilitated by emotion, this movement creates collective effervescence, which human beings have interpreted as 'sacred' throughout history. So while cooperation may be difficult to achieve, the gift of divine presence makes it more than worth the cost.

As Durkheim makes clear, the union of individual and society is never a one-way movement, each is penetrated by the other, thus there is no pure 'individual' nor is the individual erased when she enters society - the two share measures of each:

Although sociology is defined as the science of societies, it cannot, in reality, deal with the human groups that are the immediate object of its investigation without eventually touching on the individual who is the basic element of which these groups are composed. For society can exist only if it penetrates the consciousness of individuals and fashions it in 'its image and resemblance'. We can say, therefore, with assurance and without being excessively dogmatic, that a great number of our mental states, including some of the most important ones, are of social origin. In this case, then, it is the whole that, in a large measure, produces the part; consequently, it is impossible to attempt to explain the whole without explaining the part - without explaining, at least, the part as a result of the whole.

DURKHEIM 1964: 325

But Durkheim takes this dynamic further: not only is the person saturated by their social reality, but what Durkheim calls the "passions and egoistic tendencies derived from the individual", and the interests of the whole remain in tension. "Therefore", he continues, "society cannot be formed or maintained without our being required to make perpetual and costly sacrifices. Because society surpasses us, it obliges us to surpass ourselves.... " (Durkheim 1964: 338). We would argue with Durkheim's supposition that humans are by nature egotistical, and only by virtue of culture, social and moral. ${ }^{4}$ Rather, we assert that both aspects of our human nature are biologically and culturally rooted. Neither can be extracted from nor reduced to biology or culture. Social desires are part of our evolutionary heritage, along with what we call egocentric desires. These

4 Durkheim inconsistently discusses homo duplex. In some works, he seems to indicate that humans are by nature egoistical and become moral through culture, but in other places he suggests that egoism and individualism reflect the cultural context. See Jonathan S. Fish (2013). 
two dueling impulses are in dynamic interaction with each other. We argue, then, for a more complicated understanding of homo duplex that includes the recognition that there is no clean distinction in the biological and cultural origins of self or society, and that each is deeply entangled with the other.

In summary, humans must solve the problem of homo duplex continuously. Rituals - including of course religious rituals - are the processes by which this is achieved. Religious rituals, at least up until the modern period, have been the most effective way of, facilitating cooperation through their ability to generate affective and emotional energy within and between participants. We continue this line of thought by arguing that, among religious structures in the United States, megachurches are one of the most successful at this goal.

Importantly, we argue that megachurches are remarkable in that they juggle the two sides of homo duplex smoothly and effectively, developing the self within society in ways that nurture both sides of Durkheim's polarity. Through energising rituals and totally encompassing environments, megachurch attendees experience intense energy that is emotionally satisfying for individuals, but can only be attained in the context of group rituals, thus requiring social participation for its acquisition and thereby not only supporting but integrating the sides of homo duplex. To be sure, megachurches create rituals and opportunities to discipline and increase self-control, selfless behaviour, cooperation, generosity, and a desire to care for others. However, one of the most dynamic marks of these churches is the focus on the other side of homo duplex - the need to exert the ego - this is evident in the uplifting of the uniqueness of the individual, the focus on personal salvation and finding your personal spiritual gift(s), and the mission for everyone to become a better person and experience more fulfillment and love. However, a person's 'YOU' is only real and special if the person acts it out within the body of Christ. Christ's body is the CHURCH and exists to serve the wider community, both locally and internationally. This presentation and call to exert the ego works well within the megachurch model because empowerment of the individual always has the goal of serving the other as part of the whole: the church, the 'body of Christ'. Therefore, it is argued that when one is acting in one's gifts, one is witnessing to the work of God in the individual; in other words, exerting the ego is framed as a way of witnessing to the work of Christ in oneself. It is presented as one's sacred duty.

Those outside of megachurches often view members as self-centred, selfinvolved, and obsessed with their own salvation, but we have also found a prominent theme emphasising the importance of nurturing one's individual gifts for the sake of family, friends, the church and in service to the wider community. In one sense, we argue that megachurches offer an effective solution to 
the individualism that deeply concerned Durkheim. Writing in France in the late nineteenth century, Durkheim was alarmed by the European focus on valuing the individual above anyone else: "This cult of man has for its first dogma the autonomy of reason and for its first rite freedom of thought" (Durkheim 1975: 65). He goes on to say that "if [individualism] does not serve something which exists beyond it, it is not merely useless; it becomes dangerous" (Durkheim 1975: 70). We found within megachurch leadership an urgent effort to go beyond simply maintaining the individualistic cultural status quo by serving both the needs of their members and empowering them to serve each other along with their national and global communities.

\section{$4 \quad$ Embodied Choice Theory}

Embodied choice theory suggests that people make reasonable choices (consciously or unconsciously) based on the needs and demands of human experience: they make choices that will increase their emotional energy; choices that will expand their access and acceptance into helpful coalitions and mating markets; and choices that will enhance their political and social capital. Inclinations toward these human success strategies are driven by cognitive systems that rely heavily upon information that comes from the body's affective systems including somatic markers attached to prior experiences. Human sentiments lead in judgment. Megachurches work by meeting human emotional needs. And human beings, as we show in the interpretation of our data, make embodied choices, and in the aftermath of these experiences, rationalise these experiences ex post facto.

While we use Collins's theory (2004) of interaction ritual chains to describe the process by which humans experience, consume, and produce emotional energy, we add to this by arguing that these processes are integral to the nature of what it means to be human. That is, humans are homo duplex, both entranced and sometimes hobbled by their selfish needs and interests, but also yearning, whether consciously or not, to be a part of a greater whole. These impulses are always deeply entangled since even our selfish desires are socially constructed and our social interests are deeply motivated by egocentric desires. Durkheim's explanation of this multifarious web in human nature is nearly mystical, but it also, we believe, points to the tragic edge that stalks the human condition across time and tradition - our successes are intermingled with remarkable chaos and tragedy. We are a species whose desires can be noble but are often tripped by deep inner conflicts that put us at odds with others, whether other groups, religions, nations, or, in the end, with our 
environment. Durkheim meditates on the inner-conflicted nature of these entangled human drives:

The body is an integral part of the material universe, as it is made known to us by sensory experience; the abode of the soul is elsewhere, and the soul tends ceaselessly to return to it. The abode is the world of the sacred. Therefore, the soul is invested with a dignity that has always been denied the body, which is considered essentially profane, and it inspires those feelings that are everywhere reserved for that which is divine. It is made up of the same substance as are the sacred beings: it differs from them only in degree. A belief that is as universal and permanent as this cannot be purely illusory. There must be something in man that gives rise to this feeling that his nature is dual, a feeling that men in all known civilizations have experienced. Psychological analysis has, in fact, confirmed the existence of his duality: it finds it at the very heart of our inner life.

DURKHEIM 1964: 326

Our theory of embodied choice dovetails with Collins's work on the processual ingredients for rituals that are critical for the way human beings create emotional energy: bodily assembly to achieve co-presence, barriers excluding outsiders, shared emotional mood, and a mutual focus of attention. The first and most basic of these requirements - bodily assembly or co-presence - is facilitated by the first step in the Megachurch Ritual Cycle: the Welcome. Megachurches are total life systems in that they seek to produce an experience that is all-enveloping, beginning with the ritual process of co-presence. From websites, architecture, and branding aesthetic, to an ultra-friendly church welcome team, to evangelism and outreach, entering a megachurch is in many ways like coming into a womb - a total system that seeks to communicate that 'you' belong and that 'you' are accepted. As one woman described her experience emphatically: "When I walked in, it was like I had come home. It absolutely was. And I had never set foot in this place before. The Holy Spirit was here, that's all I can say, and still is". Another concurred: "I have never felt so welcome in my whole life". We know from our data that the experience can be quite electric, and that it leads to a feeling of being comfortable, accepted, loved, and welcomed. Upon entering, people don't feel judged, looked down upon, or conspicuous. Attendees report feeling like they really 'fit in'. For many, entering a huge venue in which everyone other than those who may have invited them in a stranger is a jarring and anxiety-inducing experience. At that moment then, the 'need' to be accepted is at its most intense, and so for megachurches, the entrance, the first impression, becomes a critical moment in determining 
whether newcomers stay or leave. What we found during our visits to megachurches as well as in our data is that megachurches think intensely about how to welcome newcomers to their venues; they choose and train volunteers to greet with smiles and warm handshakes and they labour to ensure that an excited sense of anticipation is triggered by signs and messaging that both direct and reassure the stranger that he or she is neither strange nor unwelcome. These experiences build on one another for the result of turning participants to Christ, and, perhaps just as importantly, to bind them to the group and institution, making them feel that this is their place and this is their community. The thoughtfulness and intentionality of these churches is remarkable and often overlooked.

Megachurches are nothing if not places where bodily assembly is critical to the energy and sense that something is about to happen. Certainly, when a megachurch venue is packed, the energy in the room 'feels' full of potential. Many would say at these events, 'expectation' is in the air, and sometimes pastors, like any good entertainer, make the people wait a bit, coming in just a little late - anticipation is built, and the wick of emotional energy in the room is lit. Crowds give the feeling of expectancy, that something is happening, that you don't want to miss it. By nature, humans find their emotions elevated and expectations increased as they gather for an event.

The next processual ingredient is critical to the process of feeling in or out and is established during the worship phase of the Megachurch Ritual Cycle - a shared emotional mood. Of course, the mood is already initiated by a greeter who is also one who guides and gives information. Coffee to one side, a place for children on the other, information for newcomers and for those who know what they want, and a friendly smiling face to give one a sense that in these churches the mood is, well, 'happy' and the greeters are happy to see newcomers. The lead into the worship service is also an 'opportunity' for greeters and ushers to introduce newcomers to the lighting, songs, and bodily movements of worship. Seats are comfortable, the singing is upbeat, often accompanied by swaying and raised hands, but nothing substantially different from what one would find at a subdued rock concert - at least not at first. Leaders voice and show that they want 'you' to be there, welcoming newcomers with announcements directed at those who are new, and displaying the vitality and warmth of the community by offering prayers for those who are lonely or in need. The collective shared mood is one that speaks volumes about the desire to make one feel not only accepted but to suggest that this is a place where the moment of 'wow' is experienced: people feel and express joy and want to share that mood of uplift with one another, or as one newcomer exclaimed, "I watched the Holy Spirit like people doing the wave at a football game.... hundreds got saved!" 
The singing and music are vital components of attendees' emotional experiences: "It's the singing: you enjoy it. [....] an hour and a half goes by and it's like we're done, can't we hear some more?" Some respondents were so touched by the musical worship that they cried: "The worship was so powerful that I was in hysterical tears the entire time. I couldn't even sing". One man described how he and his wife "were kind of blown away by the theatrical set. [....] It touches every modality that we have. And so it was kind of [like] 'Whoa'. Respondents noted how powerful it was for the entire congregation to be engaged fully in the worship: "The singers can stop singing. [....] You can stop the music and that place will still be vibrating because the whole congregation is singing". One participant said, "There is just nothing more powerful than when 10,000 or 11,00o people [are] singing at one time". Another respondent noted how during this time, people are "standing up and excited"- they are "into it" so it feels very "alive". It was common for respondents to describe the emotional energy produced by the worship as "huge" or "unreal" or to use expressions like "wow" or "whoa".

The production of high levels of emotional energy is clearly demonstrated in the interviews, which are permeated with words conveying emotions and senses. Individuals described their megachurch experience with emotive and sensory terms, such as (word frequencies): loving (385), feeling (680), amazing (81), awesome (43), exciting (51), wow (56), crying (29), touching (38), and feeding (56). The worship and sermon combined to create a powerful emotional experience for attendees, who described this experience in vivid and ecstatic ways - as a high, a drug, a feeling, energy, life, the Holy Spirit, and so on. One respondent expressed how the music energizes him: "I love coming here to a concert every Sunday. It's the bomb. [...] It just energizes you that you never know who is going to be there". Similarly, another said, "And we loved it [the worship service] because of the energy and it just recharges us". One man raved about the effective preaching of his pastor and how it "opens you up" to God, such that "God's love [communicated through the sermons] becomes [....] such a drug that you can't wait to come get your next hit". One interviewee compared the preaching from the pastors to youth camps. He explained, "You'd go to these youth camps and you would come back just so jacked up and then [.... you'd get back to the church [i.e., his previous church] and its already pulling you back down, but this was the first church [i.e., the megachurch] that we ever walked into where I felt like I did coming out of those camps. And that was every Sunday".

A female interviewee in another focus group responded by describing the feeling of being "jacked up" as a "spiritual high". Many respondents identified needing the experience and used sensory terms such as "hunger", "thirst", "being fed", and "feeling" to describe it. Indeed, the lively and powerful singing and 
music are important for attracting individuals and keeping them in the church. One attendee described how the singing and music keep individuals coming to the church, including herself: "I think this [the worship and music] is why it hits people right away. So they don't want to miss the singing and worship and see all these people enjoying this". Many respondents concurred. In other words, the intentionality and focus that goes into creating a viable co-presence intensifies and initiates a shared mood, and this is only the beginning of what's coming.

The third processual ingredient is a mutual focus of attention, and this comes through with singers and song-leaders, but culminates in the sermon or "message" and the key focus is on the pastor or lead teacher who is almost always male. As Collins summarises, "At peak moments, the pattern tends to be jointly shared among all participants: in high solidarity moments, bodies touch, eyes are aligned in the same direction, movements are rhythmically synchronized" (Collins 2004: 135). As if on cue, Collins describes the power of worship services in megachurches in which bodies are aligned, often moving, in rhythm with one another, to the song, and then with heads pointed forward, as the pastor begins to preach. Through the preaching, a desperate need is expressed, in that each person is, in some sense, found wanting, a sinner. The minister is clear that he too stands in judgment, but that is quickly followed by the declaration that while he's human and has many flaws, he also knows that in Christ, the solution is found, that new life is available, that anyone can claim this life, and that the whole world is offered this free gift of grace. In other words, the worship service messaging emphasises and creates a sense of need, which is immediately followed by the redemptive inspiration that there is a way out, that relief is within reach, that one can be delivered and that there is a solution. Thus, the leader, who relates to you and knows where you have been, presents to you this way out, a solution that liberates you from the grip of sin and confers access to God, the Father who knows you, forgives you, and wants more than anything else to save you. So, the focus of attention is the charismatic leader, the reliable leader, who while human, has found a way through to the Father that will never fail. And this Father is not like one's earthy father, but he is one who will forgive, release, and send you out into the world a new woman, a new man, delivered and guided into a new life in Christ.

Megachurch pastors are invariably charismatic figures, whom Collins calls energy stars. They take centre stage and become the key focus of attention, making them critical to the growth of megachurches. One megachurch member made an analogy between his senior pastor and the Energizer Bunny, stating that he is always on top of whatever God asks of him: "[Senior pastor] is totally led by the Holy Spirit. If God is telling him this is what we need to do, 
then he's all on it. He's like that bunny, that bunny that goes like that". Another described her senior pastor as constantly working and wondered how, as a person, he could do everything he does without being drained: "I'm thinking when do you [the senior pastor] sleep? [....] I'm drained on Sundays [....] and I can imagine if it's draining for me what it is for him, he's doing it [the sermon] three times". She then answered her own questions: "When a person is anointed and appointed by God, the Holy Ghost is going to take over. You know you are not going to be operating [on] your own strength and your own endurance. [.... You know you're not ordinary, you're extraordinary". She suggests that the senior pastor's ability to do what seems superhuman is through supernatural intervention, which gives him the strength and endurance he otherwise would not have. The senior pastor and his sermons also evoke emotional responses in the attendees. For example, one respondent said, "He blesses me to no end and I love that in him. [....] He's such a courageous speaker; transparent; baring his soul. When you hear his voice, you feel relieved. He's just that good. He's good. He's good and I love everything that he does". Attendees were emotionally affected by the words and behaviors of their senior pastor: "When [the senior pastor] stands up there and tells us we pray to God to send us the people that no one else wants. [....] How can that not affect you? You know he's our spiritual leader and we believe in him, that's why we're here. You know we love him and we trust him and we want to do what God's told us to do". Here we can see that the emotional connection is bidirectional — the attendees feel love from their senior pastor and they in turn feel love toward him. One respondent emphatically declared his positive sentiments toward the senior pastor: "He's on fire. [....] He's the shepherd". Others shared similar feelings; another mentioned how the senior pastor has "got a regiment that will follow him off the cliff" and another said that the senior pastor is "revered because he knows his flock [.... and] connects with people".

There is really no way to overestimate the impact of the senior pastor on the vitality of these churches as total environments. In one case, as senior author, I visited the site of a megachurch, where a former, longstanding charismatic pastor had been relieved of his duties a year earlier due to sexual relations outside his marriage. A new and much younger pastor had been called to the church. I visited to see how the church was faring; it was clear that the new pastor didn't have the same charisma. The sanctuary, built to fit 8,ooo, had curtains cutting the seating in half, and the energy of the place felt depressed at best. I met the pastor afterwards, and my primary impression was that he was depressed himself. He was a dynamic young man, but had stepped into shoes that he could not fill, and the experience seemed to drain him, quite literally, of energy - his emotional tone was depleted. I felt it and walked away feeling bad 
for him. This is not what one finds in energy stars, and it generally means the beginning of the end of a megachurch, which in this case, occurred not too long afterwards.

Collins's fourth and final processual ingredient is barriers excluding outsiders, which is revealed during the fourth phase of the Megachurch Ritual Cycle: the altar call. Collins explains that emotional energy is normally heightened in the context where barriers exclude what are perceived as 'outsiders'. These barriers reduce distractions (facilitating the sense that what's happening here is all that matters) and enhance the feeling of an engaged in-group. As humans, we have a sense that if some place is off limits there must be something worth seeing and experiencing in that place. What is fascinating about megachurches is that there is nearly none of these typical barriers. In this way, megachurches are a part of the broader trend of "new paradigm churches" in which individuals are encouraged to "come as they are" to services with the clergy and attendees dressing informally (Miller 1997). Indeed, wherever we visited a megachurch as part of our research, both those churches in our research sample and many more beyond our sample, the message communicated was always 'you are welcome'. No matter the venue, people were welcome, overflow spaces were available, no one was left out. A mother and new member described how her previous church required one "to wear your Sunday best", which was difficult for her children. One of the things that stood out the most to her about the megachurch was that people could wear whatever they wanted and that her son could "wear his jeans". Others mentioned the benefit of being able to go to church in regular clothes - "shorts, flip flops, whatever" - and highlighted how this made visitors, including homeless individuals, feel comfortable attending. Indeed, in the two churches that were majority African American, and another that was majority Hispanic we were struck by the fact that even when, and perhaps especially when, we were the only white person in the room, the welcome was intense and overwhelming.

That being said, the door may be theoretically open to all who want to come, it is also true that in nearly every megachurch we studied, there is clear discouragement of gay relationships and a refusal to perform gay marriages. So, for members of the LGBTQ community and their allies, these barriers are high and the costs are often insurmountable. Although, even here, some contemporary evangelical megachurches are slowly becoming more inclusive on some social issues. Indeed, one of the surprises about megachurches is that there is a diversity of positions on these more controversial issues. Even in churches where gay marriage is not celebrated, we've interviewed gay couples who feel "welcome" even if their marriages are not. 
Perhaps, if there is anything that separates insiders from outsiders, it is whether one can feel the affective and emotional pull of the services. Indeed, the primary barrier excluding outsiders in megachurches is that true insiders must feel the presence of the Holy Spirit, pledge one's faith in Jesus Christ and a pledge to support the church monetarily in one's service to the community. And to be sure, either a person experiences a 'tug' that moves them into the emotional energy of the group (whether they respond and give in or reject it), or a person may feel nothing but astonishment at the strange reactions of others; not everyone responds to or is interested in this particular type of emotional energy.

Indeed, if one doesn't feel the sense of the crowd or doesn't share the emotion of the group, a situation can quickly become excruciating, and those who are self-conscious quickly head for the exits. But for those who sense that this is their place and these are their people, there is almost nothing quite like participating in an ecstatic group in which you feel the emotions of inclusion. Indeed, in one of the megachurches that one of us attended, the pastor would put up his Bible and then move it across the large sanctuary, and everywhere he would go, a wave of folks would rise and then sit as the Bible passed; it created enormous energy across the crowd and as the pastor's Bible hovered over large swaths of people, the crowd became giddy as the wave initiated by the Holy Scripture came upon them and then went over them.

The combination of Collins' four processual ingredients produces a powerful emotional experience for participants. Megachurch attendees leave church charged with emotional energy from the interaction ritual, but it immediately begins to wane the longer individuals go without participating in subsequent events. Indeed, many members reported how terrible they felt when they miss church services. For instance, one explained, “I didn't miss a Tuesday and Sunday until this week. And I was miserable" and "I hate to miss a Sunday of church because my whole day's off". One woman described how the church service fills her and her husband up and the emptiness they experience when they miss it: "My husband always says that he needs to come on Sunday. Because it gives him a brand-new feeling for [the] entire week. [....] And sometimes when we miss it [....], we felt like so empty. [....] I know it's crazy to say this, but we really need it. And we are more happy". One member expressed this desire by wishing that he could have the same experience throughout the week: "I would just love to start every work day here for an hour. [....] It's just, you leave here so exuberant and then it's on us, I know it is, but it's so easy to get back into that rut". To help address this desire, megachurches continue the interaction ritual chain with links outside of the worship service. Within the model of the 
Megachurch Ritual Cycle, small group activities act as pit stops between Sundays. As one member described: "We get poured into from the sermon. [....] But during the week we may not get poured into [....] and some of the small groups are for us to get poured back into from each other". Another said, "And I can't go just Sunday morning and close the door [...]. I want relationships throughout the week".

The desire to maintain emotional energy throughout the week led many respondents to join small groups, which further developed their attachment to the megachurch and enhanced feelings of belonging and acceptance. This contributes to the creation of the total institutional environment. In the words of the participants, these groups help individuals "build relationships with one another in the body of Christ". They do not put "pressure on you" or "judge" you, but instead are people that one "does life with" and whom you call if you have a problem. Small groups are the "real arms and hands and feet [of the body of Christ] to love and support people". These small groups make the large church feel small: "But I don't consider this a big church because it is broken up into little groups. We're all part of the same ministry and when we see each other it's like a family". Through small groups "you develop relationships and [...then] this megachurch becomes just one little small church". Consistently, respondents identified that they felt at home and accepted, that they belonged in the megachurch, which was in large part due to participation in small groups. Small groups are enduring and tremendously effective in creating support networks and communities of friends, thereby sustaining loyalty to the group, all the while maintaining the emotional energy generated from the church services. Thus, the emotional energy creates a desire for more involvement and for a totalistic environment.

In the Megachurch Ritual Cycle, worship is never understood as a once-aweek Sunday event. The invitation and expectation are not only to enter 'into Christ' but also to enter into community, to mark oneself as a member of the family, and to discover your strengths and purpose to serve others. Therefore, service projects and opportunities constitute second chain link outside of the Sunday service and an integral phase in the Megachurch Ritual Cycle. The identity of evangelical Christians is inextricable from the call to serve the world in the name of Christ - to be Christ's body, his hands and feet, within their communities and throughout the world. This process then is one in which one not only takes on a new identity 'in Christ', but one's gifts are identified for the sake of serving the community and one's neighbour. Members are invited and encouraged to participate in all sorts of service projects aimed at enacting the identity of work of Christ within the wider community and world. Being a part of the 'body of Christ' is presented as a duty to serve, give, and spread the word. 
This has the dual effect of filling participants with a sense of purpose and direction, while also signaling to themselves and the rest of the group their devotion and loyalty to the gospel message and to the church community.

The megachurch model is designed as a total life system, and in the process of accepting God's grace, one is invited into small groups that underscore, develop, and reinforce one's new identity and that further solidify membership and commitment to the church. Small groups and opportunities to serve are vital ingredients for the megachurch model because they function to enact and mobilise what is learned (symbols) and gained (emotional energy) during the worship service, molding these into cohesive personal identities and a vibrant, cooperative community (supported by sub-communities and small groups) which permeate the rest of their lives, both individually and communally. In a pragmatic sense, they create a bridge from Sunday to Sunday to keep the fire burning throughout the week. And in a theoretical sense, they provide two vital 'chain links' in the sense of Collins's interaction ritual chain. The Sunday service, as we have shown is a solid interaction ritual complete with each ingredient; however, interaction ritual chain theory suggests that the emotional energy gained in one interaction ritual is carried with each person to the next interaction ritual they engage in. If one goes too long between interaction rituals, their emotional energy fades. Small groups and service projects provide members opportunities to express, share, and recharge their emotional energy stores throughout the week so that by Sunday they are almost just as 'on fire' as they were when they stepped out of the auditorium the week before.

Of course, both of these chain links within the Megachurch Ritual Cycle service projects and small groups - are interaction rituals in and of themselves, even as they contribute to the larger chain initiated in the worship service. Our focus on these elements emphasises the importance of what sociologists Edward Lawler, Shane Thye, and Jeongkoo Yoon $(2009,2014)$ call the micro-tomacro process. They extend Lawler and Yoon's 'relational cohesion theory' (1996) to explain how social interactions that include joint tasks, shared responsibility, and social unit attributions can accumulate to transform a network of individuals and pairs of individuals into a cohesive, centralised group. That group, in turn, becomes an object of commitment, loyalty, and immense positive affect. "In an individualized world", they explain, "group ties are self-generated from the bottom up. That is, they develop and are sustained through repeated social interactions that take place around joint tasks or activities, promoted and framed by the group unit ... [that] involve affective sentiments about the group itself" (Lawyer et al. 2014: 79).

This is directly related to Durkheim's homo duplex: "How do individualized, privatized actors create and sustain affectively meaningful social ties to social 
units - relations, groups, organizations, communities, and nations?" (Lawyer et al. 2014: 78). The answer: the micro-to-macro process. Megachurches including each interaction during the worship services, small group meetings, and outreach social service activities - are complex collections of micro units that facilitate and enact macro impulses of devotion to the larger group. Through this process, individuals' commitment expands to motivate not only service for the church, but also service for its surrounding community, the state or nation, and even the world with the life-changing' and 'world-transforming' power of the message of Jesus Christ. And here, it is not only a big-picture view that one is called to but a process by which members are invited to first, 'discover their gifts', then 'develop their gifts', and ultimately to be called to 'use their gifts' on behalf of Christ. Thus, as we have suggested all along, this micromacro project, resonates with a way to solve the tension Durkheim outlines in homo duplex, one is in-between, caught halfway between the self and the world, and the individual needs to be deeply invested in both, even at the same time. Megachurches understand that model, and create a system that functions to do both - develop individuals in their gifts, as well as to bind these folks together in a community, small and large, in which to find rest, strength, co-presence, a shared mood, tools to develop oneself, and opportunities to help and serve the world. The genius of these institutions is that they meet the needs of individuals but also maintain a focus on their communal context. And when they serve, they do so in ways that use individual gifts that serve the person, the megachurch community as well as the wider community and the global setting.

Megachurches as Small Towns

Megachurches present themselves like small towns - communities that welcome all, where every conceivable form of care is given, like hospital clinics for 'every sinner and sickness'. The needs of the many are tended to from birth to death: there is prenatal care, newborn care, childcare, schools, youth sports leagues, after school tutoring, college prep help, college-age activities, singles groups, marriage classes, car maintenance facilities, hair salons, job search help, dance classes, fitness classes, recovery resources, medical care, Senior living facilities, even a columbarium at one church. For some churches, it seemed as though if you didn't want to, you'd never have to utilise a secular resource again. Whether intentional or not, there seems to be an attempt to create a utopic community that Christians can reside in without fear of impinging secularity. 
The church structure wraps each member in community and constant fellowship with like-minded people. Because of the size of megachurches, there is enough visible variety to make the community feel vibrant and exciting, but in fact, in terms of diversity, whether delineated in terms of other opinions, lifestyles, or values, there is little to no diversity. In the vision of Peter Berger, the megachurch provides a sacred canopy with members who know the outside world, because most work in it, but choose to live within the constraints and continuities of a world in which one's beliefs are mirrored back to them as good, true and beautiful. This kind of reinforcement creates a sense of contentment that the world can make sense again. Small town America can indeed exist, where traditional values of hard work, doing the right thing, and finding like-minded neighbours is possible. We saw this repeatedly - most sermons avoid controversial topics or alternative ideas, instead they function to set up and maintain basic but solid plausibility structures of beliefs and actions. They focus on creating and supporting members' sense that the evangelical theology and lifestyle is entirely possible and eminently preferable to all other options - it is what God wants and what the Bible commands. Megachurches, even when they are in the midst of metropolitan areas, embody an imaginary of a comfortable small town atmosphere, in which one feels that one can trust others, one knows what to expect, and one can nestle into this enclave of peace and well-being.

\section{Conclusion}

In describing megachurches in this way, we've painted them, in some sense, as idyllic worlds of 1950s America. But this isn't altogether true, since the problems of the 21st century are deeply intertwined in all of these communities. So, while on the surface it seems that things maintain a conventional morality of yesteryear America, these churches are also deeply committed to taking on the real-world problems of present day culture, whether these issues are in the inner cities, or in the suburbs, megachurches are facing the central issues of our era. To be sure, they typically don't comment at all on larger political issues. And this is somewhat of a shock to outsiders, because the conventional sense is that these churches are breeding grounds for the Christian Right, and while members certainly participate in those kinds of organisations, megachurches themselves are not promoting these issues from the pulpit, even if the conservative position is subtly assumed in the prevalent rhetoric.

In a certain sense, evangelical megachurches practice a parochial cosmopolitan experience. That is, from one angle of vision, LGBTQ issues are not 
addressed. Gender transitioning is not addressed. Political candidates aren't supported at least in any explicit fashion. Megachurches instead present themselves as focused on the core issues of salvation, growing each person's character, building communities of happy, healthy marriages and families, and reaching out in service to their communities, serving the needs of the people who are homeless, sick, or hungry, and sometimes also taking this work overseas in similar international service ministries. Their explicit stated core and crucial purpose is to share the gospel of Jesus Christ, there is nothing that is more important than commitment in one's heart to Jesus Christ. And all are invited to this committed relationship. How this faith and purpose is ideally lived out is nurtured in a family-centric way, with care of others, forgiveness towards enemies and goodwill towards all.

As we have shown, megachurches are sociologically remarkable because they complete a complex ring of desire for many human beings. They make many feel welcome; they give people a sense that something special can and will happen in this place; the pastor dives deep into their psyches to answer the questions that many are facing today, and pastors quite often meet that question with an answer - but also with a request - to commit themselves to Jesus Christ. Deliverance from all things, whether uncertainty, drug addiction, violence, despair, whatever it might be, is offered in this follow up: Come forward and be delivered, be counselled, be loved by professionals, and cared for by family, those who know what you are going through. And then be ready to be challenged to service, to give one's life and goods for others, in care for the needy, for those who are local and those who are global. And finally, none of this is done in isolation, but in relationship to one's small group, a community of like-minded people who struggle and want to be healed. The Megachurch Ritual Cycle offers a church experience that constitutes a full arc of coming in as an individual and leaving fully embraced in a community of faith and love. Megachurches create powerful totalistic communities of love, support and service and the emotional energy that sustains this arc of desire is captured and personified in the belief that Jesus Christ is Lord. Now, of course, all of this can go terribly wrong and become subject to destruction; megachurches are not exceptions to the rule that power and money corrupts.

Our conclusion: Megachurches provide remarkably successful total environments because they are particularly good at generating the processual ingredients of interaction rituals and meeting the desire for emotional energy among attendees. We argue that megachurches are an astonishingly effective solution to the problem of homo duplex: binding people together in cooperative moral communities held together by cohesive, affective interaction ritual chains. 


\section{References}

Collins, R. 2004. Interaction Ritual Chains. Princeton, NJ: Princeton University Press.

Corcoran, Katie E. and James K. Wellman, Jr. 2016. “People Forget he's Human': Charismatic Leadership in Institutionalized Religion." Sociology of Religion 77:4, 309-332.

Durkheim, E. 1964. [1914]. "The Dualism of Human Nature and Its Social Conditions." In K H. Wolff, ed, Essays on Sociology and Philosophy. Columbus: The Ohio State University Press, 325-339.

Durkheim, E. 1975. [1898]. "Individualism, and the Intellectuals." In W. S. F. Pickering, ed., Durkheim on Religion: A Selection of Readings with Bibliographies and Introductory Remarks. Cambridge: James Clarke \& Co.

Fish, J.S. 2013. “Homo Duplex revisited: A Defense of Emile Durkheim's Theory of the Moral Self." Journal of Classical Sociology. 13:3, 338-358.

Hochschild, Arlie Russell. 2012. The Managed Heart: Commercialization of Human Feeling. Berkeley: University of California Press.

Lawler, E.J. and Yoon, J. 1996. "Commitment in Exchange Relations." American Sociological Review. 61:1, 89-108.

Lawler, E.J., Thye, S.R. and Yoon, J. 2009. Social Commitments in a Depersonalized World. New York: Russell Sage Foundation.

Lawler, E.J., Thye, S.R. and Yoon, J. 2014. "Emotions and Group Ties in Social Exchange." In J.E. Stets and J.H. Turner, eds, Handbook of the Sociology of Emotions: Volume II. Dordrecht: Springer, 77-101.

Miller, Donald E. 1997. Reinventing American Protestantism: Christianity in the New Millennium. Berkeley: University of California Press.

Riis, Ole and Linda Woodhead. 2010. A Sociology of Religion Emotion. Oxford: Oxford University Press.

Thumma, S. and Bird, W. 2009. "Not Who You Think They Are." Hartford Institute for Religion Research. http://hirr.hartsem.edu/megachurch/megachurch_attender _report.htm. Accessed 2/5/2011.

Thumma, S. and Bird, W. 2011. "Database of megachurches in the U.S." Hartford Institute for Religion Research. http://hirr.hartsem.edu/megachurch/database.html. Accessed 2/5/2011.

Thumma, S. and Travis, D. 2007. Beyond the Megachurch Myths. San Francisco: Jossey-Bass. 